\title{
Review
}

\section{The civic constitution: Civic visions and struggles in the path toward constitutional democracy}

\author{
Elizabeth Beaumont \\ Oxford University Press, New York, 2014, xvi+368pp., ISBN: 978-0-199-94006-6
}

Contemporary Political Theory (2016) 15, e33-e36. doi:10.1057/cpt.2015.45;

published online 18 August 2015

If there is a driving purpose to Professor Elizabeth Beaumont's book The Civic Constitution, it is to prove that regular citizens have regularly advanced new readings of the US Constitution through 'a history of contestation' (p. xv). Academics already familiar with the bounty of scholarship on popular sovereignty will want something more, and on this score Beaumont proposes a framework she calls 'the civic constitution', which overlaps with, but should be treated as conceptually distinct from, official interpretations of the Constitution (p. 3). The civic constitution is American society's all-purpose repository of legal ideas, relationships and institutions. Within its boundaries may be discovered mainstream theories of political organization, along with more radical visions of law and community - at least within certain limits, that is, 'constitutional reform' efforts shorn of violence. Although the concept is more capacious, Beaumont applies it to four periods of intense debate: the colonists' separation from Great Britain and the formation of state constitutions, the ratification of the 1787 US Constitution, the passage of the Reconstruction Amendments and the addition of the Nineteenth Amendment.

The Civic Constitution is well researched and sensibly organized. Methodologically, the study draws more deeply from extant literature featuring cultural and historical studies rather than from straight-ahead jurisprudential analyses or theoretical models. Beaumont does an admirable job showing that constitutional struggles have always entailed sharp differences over conceptions of the good life. She rightly points out that during the Revolutionary period, American colonists seized for themselves the right to make collective judgments as to the meaning of fundamental law. Her treatment of the ratification debates recalls how public debate altered the very theory of democratic constitutionalism for ordinary Americans.

As with any treatment of popular sovereignty, prickly definitional disputes can arise right at the start. One matter concerns the line between permissible means of constitutional resistance and unprincipled acts of violence. In fact, Americans have long struggled over not only substantive ideas of liberty and equality, but also the

(C) 2016 Macmillan Publishers Ltd. 1470-8914 Contemporary Political Theory Vol. 15, 3, e33-e36 www.palgrave-journals.com/cpt/ 
propriety of popular methods for defending these values. Beaumont initially appears to exclude from her account of popular sovereignty 'armed threats and violence', treating non-violent activities alone as 'legitimate and beneficial' to political order (p. 21). She argues, quite sensibly, that violence launches destructive cycles of violence, but that feels like more a strategic judgment about effectiveness rather than evidence that the political tradition has decisively rejected more forceful methods.

While Beaumont emphasizes conventional means of debate throughout the study such as speech and assembly, she also endorses civic disobedience to 'reform' higher law (pp. 57-60). The author approves the shelter of runaway slaves, which held out the prospect of violence, but would she countenance such practices as the creation of armed citizen groups to resist the return of fugitive slaves or slave stealing, which entailed waylaying traveling slaveholders and liberating slaves whether or not they had asked for help? Beaumont describes radical abolitionists such as David Walker as 'constitutional reformers', even though Walker called on slaves to seize freedom for themselves, raising the tantalizing possibility of both bloody uprisings and black selfgovernance. At the same time, the author decries the oral harassment and physical harm encountered by abolitionists from pro-slavery forces as 'mob' activity (p. 146), rejecting such actions as illegitimate forms of constitutional dialog. All of this suggests that latent principles of harm or civic virtue may be at work in Beaumont's theory of constitutional disobedience, but their contours might benefit from further delineation.

Early on, the author asserts that force is permitted only in 'a state of war' (p. 21), but a later observation that John Brown's attack on Harpers Ferry amounted to 'justifiable rebellion' suggests that Beaumont's approach might actually be quite a bit more permissive of extralegal tactics in the name of higher law. Of course, there would be far-reaching ramifications from holding that a state of war can exist whenever the grievances of one subnational group are sufficiently serious and have gone unanswered for too long. Would the steady erosion of the slaveholding states' power over their political economy justify secession? Similarly, modern separatists, whether one finds them among the sovereign citizen movement or advocates of ethnic nationalism, believe that their political rights, cultural identity and social standing have been so degraded that they would be within their rights to employ revolutionary methods. At what point does reform become revolution, and what is the relationship between the two? The Civic Constitution doesn't answer these questions, and to be fair, it doesn't set out to do so, but the author's decision to venture beyond conventional dialog occasionally does raise these recurring questions about some of the more unruly aspects of constitutional politics.

After discussing the framing of the US Constitution, the book pivots to ratification discussions surrounding Reconstruction and women's suffrage. These sections draw capably upon the current state of scholarship, which has underscored the role that social movements can play in promoting constitutional change. For Beaumont, constitutional politics at its essence concerns the struggle for equal respect within civil society. 
Ultimately, all studies of popular sovereignty are judged according to what they tell us about the constitutional process writ large. This is the central question that all works of popular sovereignty should aspire to answer, after exploding the myth that formalism is enough to explain the non-linear paths that America's constitutional history has taken.

A strong theme running through the book is the centrality of oppositional ideas. Beaumont's work uncovers, if it does not fully explicate, a powerful dialectical relationship between mainstream and radical methods of constitutional lawmaking. This rhetorical or social relationship appears to be instrumental for all involved, but it might also imply something else about how the deeper processes of constitutional lawmaking work best. As Beaumont points out, when John Brown's attack on Harper's Ferry failed, other abolitionists, including William Lloyd Garrison, distanced themselves from Brown's methods while doubling down on his aims. If extremism invites denunciation and often disqualifies practitioners from leadership positions in the constitutional regime to come, zealotry in the name of fundamental law might nevertheless change the social field upon which constitutional politics plays out, creating rhetorical space for others actors to claim the middle ground.

If The Civic Constitution is read for a normative, rather than merely a descriptive, account of foundational change, one is left a bit uncertain as to what this socio-legal process should look like once we leave formalism behind. Article V of the 1787 Constitution spells out a detailed process for proposing and ratifying amendments. At the same time, much was left undecided by the Framers. Unlike a number of state constitutions, the US Constitution does not enshrine the right of popular sovereignty, but neither does it explicitly forbid the people to alter fundamental commitments outside of the amendment process.

One possibility is that there is a single meta-process permitted by the American political tradition, a set of rules that follows the spirit, if not always the letter, of the Constitution's amendment process. A number of theorists have offered a version of this thesis. Beaumont's critique of Bruce Ackerman as insufficiently attentive to unsuccessful movements and unelected 'civic founders' (pp. 8, 12-13) suggests that she rejects this more forgiving, but ultimately formalistic approach.

Another possibility is that valid constitutional change occurs whenever a recognized institution rationally incorporates new ideas, as when the Supreme Court does so according to the common law method of interpretation or when something akin to an institutional consensus over new foundational norms can be said to have arisen. This approach to constitutional lawmaking - exemplified in the writings of David Strauss or Benjamin Cardozo - pushes original intentions to the background in favor of other criteria to determine legitimate legal change, but the book's focus on ratification debates makes it difficult to develop a thesis along these more acute institutional or cultural lines. The book does not take a position in modern jurisprudential debates over how judges ought to interpret the Constitution. 
Still another, more wide-open theory of sovereignty that many citizens find appealing holds that legal changes are authorized whenever a representative group of Americans takes it upon itself to propose or enforce new constitutional norms. The challenge for this approach is to identify what, if any, constraints exist on such claims of self-governance. If none can be found, then sovereignty is no longer about law, but rather about raw power. At times, Beaumont seems sympathetic to the second and third theses, at least to the extent that anyone can try to restart the engine of constitutional change. Even so, the study's overall design indicates a baseline commitment to the codification of broad-based changes and (perhaps) an underlying skepticism that more subversive tactics are sufficient to generate binding legal norms.

Even if it does not supply a grand theory to replace any leading accounts, The Civic Constitution nevertheless directs attention to 'forms of civil resistance' and 'acts of hope' within the most repressive legal orders (p. 152). It urges scholars to embrace complexity in the answers we seek (p. 214), and ordinary citizens to keep alive the possibility of reinvention.

Robert L. Tsai College of Law, American University, Washington DC 20016, USA 